\title{
Getting Things Done
}

\begin{abstract}
This chapter reviews the main governance challenges policymakers faced during the COVID-19 crisis. It examines how governments mobilized institutional capacity to tackle these challenges. We focus on attempts to centralize crisis decision-making and discuss whether centralization contributed to government effectiveness and legitimacy.
\end{abstract}

Keywords COVID-19 • Crisis decision-making · Centralization · Effectiveness - Legitimacy

\section{When the Rule Book No Longer Works}

The virus tested the capacity of nations and societies to deal with a cascading threat that had no precedent in the post-war era. When the potential impact of COVID-19 came into view, governments faced the critical challenge of protecting the health of their citizens, the viability of businesses and industries, and the functioning of critical infrastructures against the onslaught of the pandemic.

A pandemic can only be quickly brought under control by bringing collective behaviour under control. The alternative-waiting for a vaccine to arrive or the virus to infect a majority of people-is both costly and politically risky. The policy options for controlling collective behaviour are limited: a government can try to persuade its citizens and businesses

(C) The Author(s) 2021

A. Boin et al., Governing the Pandemic, https://doi.org/10.1007/978-3-030-72680-5_3 
to adhere to social distancing guidelines (the path taken by Sweden) or force them to do so through some type of lockdown regime (the preferred option in most countries). Persuading businesses and citizens to make jarring sacrifices presupposes that governments can draw on reserves of political trust (Cairney \& Wellstead, 2020); forcing them to do so requires the willingness of leaders to use force, which may cause the reservoir of trust to erode.

These options can be designed and implemented in many different ways, and the pandemic regimes that emerged in those first months of 2020 varied accordingly. We can group the pandemic regimes along several dimensions: the number of social distancing measures (working from home, closing down public events, limiting travel, closure of restaurants, bars and schools), the sanctions imposed, the ways of enforcement, the level of compensatory funding (for COVID-19 response patterns, see Bouckaert et al., 2020; Cheng, Barceló, et al, 2020).

In choosing between these options and designing an optimal policy mix, leaders had to balance imperatives of public, economic and social health (Dostal, 2020; Polischuk \& Fay, 2020; Rauhaus et al., 2020). Lacking evidence-based insights (as we have seen in the previous chapter), leaders had to make 'tragic choices' (Calabresi \& Bobbitt, 1979): whatever they decided, there would be losers. In making such choices, government leaders typically apply political filters (Maor et al., 2020): how does the issue look and feel to (different groups of) ordinary citizens? How will the policies recommended by the experts play with stakeholders? Are these proposed measures politically acceptable, in the coalition, in parliament, to the party base? Can we afford what is being proposed here? Do we have the capability to implement it?

Whatever choices they made, there were no plans readily available to translate them into coherent policy regimes. Even though most countries had some sort of pandemic preparation in place, they soon discovered that the core assumptions underwriting their plans and procedures, as collected and disseminated by the World Health Organization (WHO), were of limited use. The WHO prescribed hygiene measures, physical distancing, isolation of patients, tracking and tracing of contacts-but did not provide templates for the closing down of society (or parts of it). Governments across the world had to improvise their responses (Capano, 2020; Turrini et al., 2020).

As we write this, experts are studying the effects of these responses. They explore correlations between infection and mortality rates, and 
a host of social, institutional, historical and political factors (varying from female vs. male heads of government to individual vs. collectivistic cultures, from climate effects to the political affiliation of leaders). This will go on for years, and it is simply impossible at this point in time to meaningfully evaluate and explain the effectiveness of all the response policies that emerged across the world (Bromfield \& McConnell, 2020). ${ }^{1}$

We will need much more data and modelling to establish whether the schools should have been closed or not, whether it made sense to limit travel, whether facemasks really made a difference, whether complete and long-lasting lockdowns were worth the price, and whether the powers appropriated and wielded by governments were proportionate. In fact, even when looking through the rear-view mirror at COVID-19, we may never arrive at a consensus, as the assessment of what was effective and legitimate, and whether that was worth the price, involves normative judgements and contestable counterfactuals.

What we can do now, however, is characterize the response challenges and interpret the crisis response efforts of Western governments during the first phase of the epidemic. From a bird's eye perspective, two remarkable characteristics of the responses stand out.

First, in spite of the variability in response policies across countries, most governments managed to bring the first wave under control. Hence, collective behaviour - the key to controlling a pandemic - may well have been shaped by a fear-driven collective willingness of people to act in a way that benefits the society of which they consider themselves members (cf. Johnson, 2020) rather than by the mix of policy instruments deployed by various governments. This should not come as a surprise: decades of research in disaster sociology and social psychology have consistently shown that people tend to act in altruistic, pro-social ways when faced with acute exogenous threats to their common values, interests and identities (Drury, 2018; Zaki, 2020).

\footnotetext{
${ }^{1}$ There are many online, ongoing monitoring efforts that are of great value in tracking and assessing response efforts and their economic, social, democratic and human rights consequences. These include the Blavatnik School of Governance Coronavirus Government Response tracker, the ACAPS COVID-19 Government Measures Dataset, Freedom House's Democracy Under Lockdown project, the Pandemic Backsliding Project and IDEA's Global Monitor of COVID-19's impact on Democracy and Human Rights, as well as thematic COVID-19 response monitors run by the European enter for Disease Control, the IMF and the OECD.
} 
We can also observe that many countries struggled to bring the second wave under control. Harnessing discipline proved more difficult the second time around. An often-heard lament during the second wave was that many people were simply tired of social distancing measures and no longer behaved in the spirit of solidarity with those at risk of the virus. That, too, is in line with crisis research findings, which note that the altruism of the early response phase tends to break down over time as social and political fault lines re-emerge, government measures are shown to be ineffective or controversial, and 'rally-around-the-flag' effects wear off (Herrera et al., 2020).

Let us now dig in a little deeper. What problems were governments confronted with, how did they respond, how did they set themselves up for dealing with such an extraordinary set of challenges in a manner that was to be both effective and legitimate?

\section{Governance Challenges}

The COVID-19 crisis immediately confirmed received wisdom among crisis researchers: contingency plans rarely survive contact with the enemy (Clarke, 1999). It is fair to say that the pandemic is one of the few crises that many if not most countries had prepared for, in one way or another. After all, the 'next pandemic' has traditionally featured on every list of likely future crises (Garrett, 1994). Modern societies have experienced just a few deadly pandemics (AIDS, SARS, Mexican Flu) since the Spanish Flu. These were brought under control and provided input for the updating of plans and procedures, as well as the creation of new institutions such as the European Centre for Disease Prevention and Control (ECDC).

It is understandable that politicians, policymakers and experts in Western countries laboured under the impression that their systems were well prepared to deal with the new coronavirus. Their surprise that these plans were no match for the pandemic is, then, equally understandable.

Surprise or not, decisions had to be made. Vulnerable populations were at serious risk if the virus was allowed to spread (An \& Tang, 2020; Migone, 2020). Hospital systems could be overwhelmed, crowding out regular care (which, in turn, would put other groups at risk). But any sort of measure imposed to stop the spread of the virus would require sacrifices 
from other people who would be unlikely to suffer any health consequences even when infected by the virus. Governments faced a complex set of immediate decisions to be made:

Influencing collective behaviour. How to induce public behaviour so as to reduce community transmission of the virus? What mix of persuasion and compulsion was deemed both effective and legitimate? When to apply lockdowns, in what form, and for how long? What place was accorded to testing and contact tracing in that mix, and how to increase that capacity?

Tragic choices in health and care systems. To what extent should government leaders step into guide life-and-death decisions in hospitals, general practices, nursing homes, aged care facilities and shelters with regard to (1) distribution of IC-beds/ventilators; (2) selection of eligible patients for life-saving treatment; and (3) deployment of critical staff in cure and care? But also: what vaccine options to invest in? How to prioritize who should receive the vaccines?

Managing scarcity. Governments everywhere were soon confronted with shortages that had to be resolved. But how to navigate the international supply-chain race to ensure continued supply of medical and other critical resources in a world that had mostly shut down? Purchasing and distribution of protective equipment and medicines required decisions about where to buy and at what price.

Managing economic upheaval. Designing, coordinating, delivering and maintaining support for mega-stimulus packages and crisis-induced monetary and tax measures is not an easy task (as the experiences during the Global Financial Crisis of 2007-2009 taught us). Political leaders had to decide how much money to spend and what to spend it on. How to dodge the known risks of delayed impact, market distortions and fraud? How to apply economic policy instruments in a way that does not throw good public money at businesses that are not going to survive? How to build in incentives for businesses to come off the government's tap as quickly as possible when conditions ease?

Addressing secondary impacts. In the face of urgent problems needing immediate attention, policymakers quickly discovered that they would have to devote their attention, political capital and operational resources across many (and the number kept increasing) 'theatres of war'. The prime focus of most governments was initially on the acute public health 
and socio-economic challenges. New challenges continued to emerge as many countries faced second and third waves: spikes in homelessness, loneliness, depression, family violence, alcohol and substance abuse; school children and students struggling to keep up or going AWOL.

Mitigating inequality. As it became increasingly clear that negative impacts were not equally distributed across the community-COVID-19 was hitting disadvantaged groups a lot harder, as always happens during a pandemic (Rosenberg, 1992)-government leaders had to decide if and how they would mitigate this inequality of impact.

Steering towards restoration or reform. Even in the midst of crisis, governments had to contemplate a post-vaccination future. Should their society "return to normal" or aim for change and innovation in health systems, in how work gets organized spatially and temporally, in business and leisure travel? Should they re-appreciate the caring professions, the social sector, the value of community? Should they try and exploit the COVID19 experience to achieve policy objectives in other domains, such as improving air quality, enhancing sustainability and meeting the Paris climate change mitigation objectives?

How leaders and governments responded to these challenges would affect not just the course of the pandemic and its many societal impacts but also the public perception of the crisis response: whether citizens thought the COVID-19 crisis was handled with poise, decency and intelligence, or haphazardly, indifferently and opportunistically, generating pubic disappointment, resentment and anger. In other words, it would enhance or deplete the political capital that leaders brought to the crisis.

\section{First Responses}

The immediate responses varied markedly across (and sometimes within) countries. They can be roughly organized into three types: the lockdown, the light regime and the absent regime. In practice, many countries adopted some sort of mixture of these regime types and many governments adapted their regimes over time. But most responses can be sorted this way, which allows us to contemplate why governments would adopt this or that type as their starting point in formulating a response.

China provided a first template by imposing a complete and unprecedented lockdown. The world looked on with a mixture of awe and 
scepticism. Critics observed that such a response was only possible in an autocratically ruled society in which mass surveillance was already widely employed. But their experience with viral outbreaks and pandemics such as SARS and Avian flu likely provided a role as well: the attitude towards pandemic risk, the availability of critical resources and the public's willingness to comply with 'go early, go hard, keep going as long as it takes'-paraphrasing New Zealand's Prime Minister Jacinda Ardernall help to explain why this draconian approach was adopted in China (Jamieson, 2020; Johnson, 2020).

When the virus arrived in Italy, the government adopted a hard lockdown (Capano, 2020), initially only in the northern regions. As the pandemic spread, variety in response regimes soon emerged. Many Asian countries, for instance, shied away from lockdowns, instead adopting a combination of frequent and massive testing, complemented with extensive track and trace policies, the cancelling of public events and the universal wearing of facemasks. At the other end of the spectrum, the US President Trump did not deem it necessary to impose social distancing measures (though many individual states did). Sweden stuck close to the regime that was originally proposed by the World Health Organization (but did not follow it when the WHO adapted its guidelines). The Netherlands, Switzerland, Austria and Germany followed versions of a more flexible approach, imposing a rump set of restrictive measures, which were tightened as circumstances required (Boin et al., 2020; Desson et al., 2020).

The nature and levels of government support for businesses and citizens varied as well across countries (Park \& Maher, 2020). Some countries were proactive in providing generous business continuity and wage stability packages. Many countries, of course, had limited means to offer such support. In the US, the design and funding of such support schemes became object of an intense political fight between Democrats and Republicans in Congress.

Many businesses, especially those in the leisure and travel industry, suffered terribly from the imposed social distancing measures, while others were largely unaffected or made a killing. Governments were besieged by lobbyists, arguing for government support or waivers from social distancing measures. Governmental decisions prompted classic questions: why did they throw billions at national airlines or big mall owners, while ignoring the dire needs of higher education (as in Australia), restaurants, museums and small business owners? 
Scarcity was dealt with in different ways. In some countries, the limited availability of IC-beds and IC-personnel could mean that patients without insurance or financial means would not be treated in an IC-unit. Other countries drew up priority listings, selecting on age and underlying conditions. Similar choices had to be made when it turned out that testing capacity was limited. In some countries, demand was limited by specifying the symptoms that were most likely to indicate that someone was a carrier of the virus (this created a skewed picture of the infection rate). In addition, certain groups were prioritized (hospital workers, teachers) or de-prioritized (the elderly). Other countries managed to avoid this type of dilemma altogether, as they had procured plenty of testing capacity (Germany, Korea).

The structural shortage of personal protective equipment (PPE) in hospitals and nursing homes created policy dilemmas, but also individual dilemmas for caretakers. In the early phase of the crisis, many doctors and nurses - including those working in 'rich' countries-had to decide whether they would work without protective gear. In hospitals and nursing homes, wrenching decisions had to be made: who would receive the few available face masks? At the policy level, the allocation of scarce, life-saving material played out in different ways: hospitals vs. nursing homes, heavy-hit areas vs. areas 'in waiting'-but also giving into price gauging vs. waiting until trusted suppliers could deliver again (Vecchi et al., 2020). Particularly notable was the way in which the American president politicized the allocation of ventilators, threatening to punish states with Democratic governors that did not "treat him well" (Wright, 2021; Young et al., 2020, p. 484).

\section{The Politics of Crisis Response}

COVID-19 demonstrated that many governments had come to rely on the market for the provision of critical goods (PPE), supply chains (food) and critical infrastructures (ICT). But it also showed that many private sector companies relied on the public sector for bailouts, regeneration strategies, enabling business activity through emergency trading regulations. The rapid development of vaccines exemplifies this mutual relation: 'big pharma' needed huge infusions of public funds to rapidly produce a vaccine and quick regulatory approval to bring it to market. A return to normalcy any time soon would be impossible without vaccines. 
Another observation with regard to the way governments negotiated these tough dilemmas was the weakness of existing mechanisms of international coordination and cooperation (Dostal, 2020). When the pandemic came, national governments were primarily focused on producing a national response. Countries did not coordinate border restrictions (in federal countries, states/provinces did not, or barely, coordinate their internal border closures, e.g. Benton, 2020; Bennett, 2021). This led to awkward situations that arguably helped to spread the virus (e.g. when Belgium closed its restaurants, people simply drove across the border to patronize Dutch restaurants). The same thing happened when countries began to relax measures (Austria and Switzerland opening their ski venues, while Germany, France and Italy were calling upon their citizens to forego ski vacations).

COVID-19 was a prime example of what we call a transboundary crisis: an acute threat that spills over national, institutional and cultural borders. Transboundary crises test governance systems that are built on the idea of such borders (Boin, 2019). The COVID-19 crisis exposed the weakness of international governance systems when it comes to managing transboundary crises (Blondin \& Boin, 2020). Rather than seeking to use existing coordination and information-sharing mechanisms, most states resorted to a form of 'crisis management autarky'. When Italy called for help, member states did not reply. When the new EU budget was drawn up, the richer member states initially refused to allocate funds for the hard-stricken southern states. This undermined the sense of solidarity that supposedly would lead to assistance of member states in times of dire need.

Harold Lasswell's (1936) articulation of politics as a question-Who gets what, when and how?-is writ large in the COVID-19 crisis. The politics of managing this crisis centred around the distribution of the consequences of crisis decisions. But the crisis also opened windows of opportunity for the distributors of scarce resources. Powerful industriesthink of airlines and tourism sector-suddenly were at the mercy of governments for life-saving bailouts. This provided government leaders with leverage to demand long-sought-after reforms. Other leaders simply used their distributive power for political gain. Prime Minister Boris Johnson used the approval of a vaccine-the first approval in Europe-as evidence for the promised Brexit benefits. 
COVID-19 presented the EU with a unique opportunity to reinvent itself as a transboundary crisis manager. A range of fairly recent transboundary crises (the Ash cloud, the financial crisis, the immigration crisis, the threat of cyber breakdowns, climate change) had enhanced the realization that these threats demand some sort of transboundary response. The European Union (EU) had begun to build transboundary crisis management capacities (Boin et al., 2013; Wolff \& Ladi, 2020). While the EU had limited formal competences in the area of public health, it had created systems for early warning and information sharing that were designed to further a joint response to an emerging pandemic. But they were not used in this crisis.

The member states resolved to strengthen the EU's crisis management capacities, agreeing on new competencies to manage public health emergencies (Brooks \& Geyer, 2020). Moreover, in what was "possibly the biggest advance in integration since the Euro", the member states agreed to a 750 billion solidarity fund (Rachman, 2020, p. 17). The money was to be raised by issuing common EU debt. Some heralded this as a critical juncture in EU economic policy and as an instance of crisis-induced EU institutional learning (which the EU had not recognized in response to the Eurozone crisis) (Ladi \& Tsarouhas, 2020; Schmidt, 2020; Wolff \& Ladi, 2020).

\section{Governance CAPACITY AND Legitimacy}

Establishing a pandemic response regime that effectively reaches across society and is embraced by the broadest possible spectrum of community actors requires not just immense effort and commitment of resources. It rests upon two critical preconditions: the capacity to govern effectively (Dror, 1986, 2001) and the social legitimacy afforded to the effort (Carter \& May, 2020). This is, as political scientists and public administration scholars have long known, true for all government efforts aimed at steering collective behaviour (Lodge \& Wegrich, 2014; Pressman \& Wildavsky, 1973). It is particularly true in times of crisis (Christensen et al., 2016). 


\section{Boosting Governance Capacity}

Governance capacity is generally measured in terms of task fulfilment: can a government leverage its legal, financial, informational and logistical systems to design, coordinate and deliver interventions that 'work' (Boin \& 't Hart, 2012; Carter \& May, 2020; Lodge \& Wegrich, 2014)? Crises challenge existing governance regimes and test the efficacy of new capacity mobilized by governments. Crises also challenge the strength of the social contract that informs and constrains the exercise of state power. That's why governments usually find it hard to 'deliver' in times of crisis.

During COVID-19, governance capacity was needed to:

- Address shortages in PPE, ventilators and hospital staffing;

- Enforce rules with regard to quarantines and social distancing;

- Allocate funds to support citizens and businesses in need;

- Ramp-up testing;

- Devise strategies to help at-risk groups and those with complex needs;

- Roll out nationwide, high-speed vaccination campaigns (and get large proportions of the population to participate in them).

These challenges proved problematic in many countries.

In times of crisis, governance capacity cannot suddenly and quickly be enlarged or enhanced without hiccups and unintended consequences (Capano et al., 2020). It is possible, however, to streamline the governance of existing capacity. This is typically done by centralizing authority and augmenting executive power.

Most countries have mechanisms to centralize state power in the hands of selected officials if a crisis so requires. The idea has always been that effectiveness sometimes must be enhanced even if it is at the expense of democratic oversight. Selected officials are then empowered to make critical decisions without having to first submit them to democratic bodies. They are granted constitutional political authority, preponderance in policymaking, access to resources and the legal authority to steer networks of institutions and actors.

The Romans had a name for these officials: they were called dictators. For a carefully delineated period of time (usually a year), one or two dictators (working in tandem) would rule the republic with absolute powers. 
The early history of the Roman Empire offers examples of absolute effectiveness, but also of the dangers that the mechanism of crisis centralization brings with it.

It is often assumed in the literature, if only implicitly, that such centralization is an almost natural if not necessary process. When the future of a society is at stake, and do-or-die decisions must be made quickly, people will not only accept but expect leaders to assume the mantel of crisis power (cf. Schmitt, 2006). Crisis researchers have subjected this claim to case-informed scrutiny ('t Hart et al., 1993). It turns out that centralization in times of crisis is rarely absolute. Seemingly centralized crisis responses typically coexist with different constellations of local power holders, private sector initiatives and resilient citizens.

Centralization tendencies are also tempered by what researchers refer to as the 'bureau-politics' of crisis governance (Jacobs, 1993; Kalkman et al., 2018; Rosenthal et al., 1991). One might expect all parts of government to pull together, set aside ongoing intergovernmental and interorganizational tugs of war and collaborate seamlessly in service of the superordinate goal of combatting the joint threat (Parker et al., 2020). In most countries, this did indeed happen during the early phases of the COVID-19 crisis, when the primacy of public health considerations and the core values were undisputed, and goal seemed relatively straightforward (see, for instance, Choi [2020] on South Korea). But the consensus fragmented as the scope of the crisis expanded. More and more departments and policy actors began to press for position in the crisis response machinery, straining cabinet cohesion and complicating the work of policy coordination.

When governments attempted to expand executive power to ensure quick decision-making and effective implementation, they faced pushback on privacy (deploying track and trace apps, appropriating and distributing patient records), accountability (assuming emergency powers for how long? Regularly informing parliaments?) and, of course, civil liberties (why should societies suspend checks and balances in the name of safety and security for the relative few?). While centralization tendencies did emerge across the board-including the high-speed crafting and passing of emergency laws-it is an open question whether they ended up boosting governance capacity as defined above. In France, for instance, important response failures were related to the rigidities that formalized centralization brought about (Hassenteufel, 2020). Much more will be learned in 
time as public administration scholars sort through all the evidence, but a few preliminary observations can be offered at this early stage.

First, it is clear that crisis centralization shaped the ability of governments to enforce and maintain heavy lockdown measures. In states where crisis decision-making was centralized, crisis governments could employ the full mixture of carrots and sticks to ensure collaboration of (and between) agencies, subnational governments, citizens and businesses. In some, the military played a visible role in keeping people off the streets and keeping workplaces closed. But in states where centralization was less than complete or not tried, governments could not rely on uniforms and fines alone. Their governments relied on alternative or complementary strategies such as 'sermons' (persuasion), nudging and piecemeal consensus-building (see, for instance, Migone [2020] on Canada).

Second, it appears that complete centralization was short-lived at best. In the course of the crisis, governments faced two types of pushback (cf. Boin \& 't Hart, 2012). On the vertical axis, regional and local administrators (mayors, governors) resisted or got tired of limitations on their discretionary powers (e.g. Van Overbeke \& Stadig, 2020). As the implementers of centrally formulated policies, they had to enforce unpopular measures. On the horizontal axis-within the executive branch-the centre of gravity shifted over time from public health agencies to a wider, more competitive arena that included economic and social policy agencies.

Leaders who were governing through a centralized power structure sooner or later discovered that their options were, in fact, quite limited. As adherence to the rules became harder to enforce because people began to lose their patience, crisis leaders had to adapt their strategies to keep as many people as possible with the programme.

Third, we can conclude that there was no one-size-fits-all administrative route to COVID success (Bromfield \& McConnell, 2020). The institutional make-up of governance systems surely mattered: centralization was harder to achieve in federal countries than in unitary states. In federal systems, centralization initiatives met with contention (Benton, 2020; Capano et al., 2020), did not happen or did not endure (e.g. US, Mexico). Australia, Canada and Germany initially designed effective regimes, but only Australia managed to eradicate the virus (Dostal, 2020; Migone, 2020; Rozell \& Wilcox, 2020). We may thus cautiously surmise that the effectiveness of pandemic regimes was not exclusively determined by political-administrative structures (cf. Capano \& Galanti, 2018). 


\section{Crafting Legitimate Responses}

Without a minimal degree of legitimacy, government cannot function. Legitimacy translates into robust support (and compliance) among the population. In a crisis like COVID-19, when collective behaviour is the key to effective management of the crisis, legitimacy is probably the most important asset that governments can possess.

During COVID-19, it proved critically important that citizens trust their government (Cairney \& Wellstead, 2020; Capano et al., 2020; Cheng, Yu, et al., 2020; Christensen \& Laegreid, 2020; Jamieson, 2020; Wright, 2021). Governments that were seen to be 'on the ball' in their COVID response activities fared well among their publics, at least initially, whereas governments that appeared to be in denial or paralysed saw drops in their credibility and support among the public (Herrera et al., 2020; Jennings et al., 2020; Kim \& Kreps, 2020). High legitimacy furthered rule adherence, which, in turn, helped to quash the pandemic (thus strengthening the legitimacy of leaders). The reverse was also true: low legitimacy fuelled shirking on the parts of citizens and businesses, which undermined effectiveness and, as a result, government legitimacy (Carter \& May, 2020; Wright, 2021).

It is, of course, helpful for leaders and governments to enter a crisis with solid levels of public support, yet crisis case studies have shown again and again that it is not essential. Being seen to do well during a crisis is a powerful booster of leadership capital (Van Delden, 2018). Examples include the Amsterdam mayor Ed van Thijn and New York City mayor Rudy Giuliani, both of whom were deeply unpopular when they suddenly had to manage major crises in their cities. Both emerged from the crisis with soaring popularity. The same can be said for Australian Prime Minister Scott Morrison. He entered the COVID-19 crisis with little public trust to spare after the botched management of the wildfires disaster in the previous months, but regained his public standing on the strength of a more astute and compassionate performance in shaping Australia's COVID-19 response.

Several other factors affected the dynamics of public trust in crisis leaders. We learned, for instance, that it is important to explain why the imposed pandemic regime deviates from scientific findings or widely accepted practices elsewhere. The use of face masks illustrates the point. Initially, there was no science to suggest whether the use of face masks would be useful. Many Asian countries (with low infection rates) quickly 
made them compulsory, relying on prior experiences and established cultural practices (An \& Tang, 2020). ${ }^{2}$ Western leaders wrestled with the question whether to emulate that example. Pointing to the lack of scientific evidence initially worked as an explanation for their decision not to. But the science began to change, and social demand for tangible, visible action rose. The same dynamics played out in the domain of education, where governments bowed to public concerns in deciding to close or open schools without robust scientific evidence.

Such inconsistencies in policy justifications became a source of discontent among citizens and business operators just when imposed measures started taking effect in April and May 2020. While scientific advisors, understandably happy that an effective strategy had been found, argued that measures were best kept in place as long as possible, public impatience with restrictions translated in an ever-louder call for their rapid relaxation. Advocates of loosening crisis regimes eagerly made use of 'new' scientific insights widely shared on social media-where the number of arm-chair virologists kept expanding-which seemed to cast doubt on the efficacy of these measures.

Crisis managers thus faced a continuing policy dilemma between 'Kantian' (everybody's life needs protecting) and 'utilitarian' (adopt measures that provide the greatest good for everybody) policy imperatives. In the absence of meaningful information, the best approach to solving this dilemma might be what is known as the 'pragmatic approach' to crisis management (Ansell \& Bartenberger, 2019; Ansell \& Boin, 2019). The pragmatist logic is experimentalist: organize quick and rich feedback flows about the policies you have put in place and act quickly on that information (adapt if initial measures are shown to be ineffective).

That is not how things generally unfolded during the middle months of 2020. We can describe what happened in terms of 'politicized' adaptation: governments caving into increasing pressure to stop inflicting social and economic pain. In many countries, leaders succumbed to the pressure and joined the rush to the exit. In hindsight, it appears clear that this hastened relaxation of crisis measures allowed the virus to persist and strike again

${ }^{2}$ The institutional and cultural memory of previous pandemics, such as SARS and Ebola, left policymakers much better prepared than their colleagues in Western countries. Previous experiences had prompted these countries to invest heavily in pandemic contingency preparedness (increasing test capacity, stockpiling PPE and formulating legal provisions) (An \& Tang, 2020). 
(An \& Tang, 2020). More importantly, it undermined the credibility of governments who soon needed to call upon citizens and businesses again when the second wave hit even harder than the first.

This final phase of the first-wave part of the crisis may well turn out to have been one of the most problematic periods in the governance of the pandemic. Deeply fatigued by the long months of 'flattening the curve' without destroying their economies, government leaders understood business and public desires to return to a normal life all too well. While the mantra in most places was that 'we have to learn to live with the virus', they swiftly allowed life to return to near-normal. Restrictions still existed, but the summer vacations in Europe and North America unfolded in eerily conventional ways. When second waves began to take shape, virologists were quick to point to the masses of travelling vacationers as being among the chief drivers.

Those leaders who-again-failed to see the second wave coming found it hard to get their citizens back on the same page of social distancing and sacrifice. Those who failed most miserably-President Trump and Prime Minister Boris Johnson come to mind-saw their public health systems buckle under ever-increasing pressure. Those who had gained public trust by highly effective responses to the first wave could leverage it to impose new rounds of 'go hard, go fast' restrictions to stamp out new spikes-as was the case in New Zealand (Jamieson, 2020).

\section{The Politics of Crisis Governance}

The COVID-19 crisis was always deeply political (Maor et al., 2020). In every country, the virus cast light on issues of authority, power and legitimacy, how the state wielded power over citizens and businesses. In some states where the relation between citizens and officials was strained before the crisis, the response was botched (see, for instance, the US). Much has been made in this regard of the willingness of citizens with high levels of trust in their governments to adhere to nudges offered by their governments (think of Denmark, Finland and Norway).

Public support was a sine qua non for crisis management effectiveness. With few exceptions, pandemic governments prioritized public health, in particular the protection of vulnerable citizens. Most sought to accomplish this through social distancing measures, lockdowns and the ramping up of emergency care capacity while scaling down regular healthcare 
services. Citizens had to cooperate to make this happen. Just how important their cooperation was, became painfully evident during the second wave when citizens in many countries lost interest in (or motivation for) rule adherence.

Trust in public authority can certainly make it easier for crisis leaders to initiate a constellation of freedom-limiting measures and a power structure that enables the implementation of those measures. But crisis management performance matters as well. Sweden is a prime example: its crisis management regime enjoyed substantial legitimacy, but the country did not perform better than countries where such trust did not exist. Australians, on the other hand, entered the crisis with a relatively low level of trust in their government (which had failed in managing the forest fires), but still the country managed to suppress the virus pretty well.

Given the importance of citizen behaviour, governments face a conundrum. Banking on citizen trust, they may seek to explain the risks and propose the countermeasures, counting on the sense of responsibility of smart-thinking people. But by explaining the risks-very low health impacts for the great majority of people-they might inadvertently nudge citizens towards pursuing self-interest above the public interest. There was no running away from the collective action problem that the virus introduced. Shying away from it by seeking to avoid the frank discussions that had to be had opened the door to inconsistent or hard-to-explain measures.

Things never get easier in a protracted crisis like COVID-19. The money to support people and businesses will run out, sooner or later. Cutbacks and austerity will erode government capacity. Perceptions of threat and senses of urgency will wane. Actors that have been side-lined during the crisis will reassert themselves, slowing down policymaking and implementation processes. Contentious politics as usual will inevitably be part and parcel of the 'new normal'.

As we write this, the roll-out of vaccination programmes in various countries has become a topic of intense political debate. Getting things done remains critically important yet frustratingly hard. As the post-acute stage of the crisis begins to loom, and governments will begin to navigate the 'long-shadow' ('t Hart \& Boin, 2001) phase of the crisis, maintaining the capacity to deliver is hugely important. The legitimacy of government and government leaders may well depend on it. 


\section{BIBLIOGRAPHY}

An, B. Y., \& Tang, S. Y. (2020). Lessons from COVID-19 responses in East Asia: Institutional infrastructure and enduring policy instruments. American Review of Public Administration, 50(6-7), 790-800.

Ansell, C., \& Bartenberger, M. (2019). Political pragmatism and crisis management. Edward Elgar.

Ansell, C., \& Boin, A. (2019). Taming deep uncertainty: The potential of pragmatist principles for understanding and improving strategic crisis management. Administration \& Society, 51(7), 1079-1112.

Bennett, C. (2021, January 5). Australia's mishmash of COVID border closures is confusing, inconsistent and counterproductive. The Conversation. https://theconversation.com/australias-mishmash-of-covid-border-clo sures-is-confusing-inconsistent-and-counterproductive- 152620.

Benton, J. E. (2020). Challenges to federalism and intergovernmental relations and takeaways amid the COVID-19 experience. American Review of Public Administration, 50(6-7), 536-542.

Blondin, S., \& Boin, A. (2020). Cooperation in the face of transboundary crises: A framework for analysis. Perspectives on Public Management and Governance, $3(3), 197-209$.

Boin, A. (2019). The transboundary crisis: Why we are unprepared and the road ahead. Journal of Contingencies and Crisis Management, 27(1): 94-99.

Boin, A., \& 't Hart, P. (2012). Aligning executive action in times of adversity: The politics of crisis coordination. In M. Lodge \& K. Wegrich (Eds.), Executive Politics in Times of Crisis (pp. 179-196). Palgrave. Boin, A. (2019). The transboundary crisis: Why we are unprepared and the road ahead. Journal of Contingencies and Crisis Management, 27(1): 94-99.

Boin, A., Brown, C., \& Richardson, J. A. (2019). Managing Hurricane Katrina: Lessons from a megacrisis. Louisiana State University Press.

Boin, A., Ekengren, M., \& Rhinard, M. (2013). The European Union as crisis manager: Patterns and prospects. Cambridge University Press.

Boin, A., Overdijk, W., Van der Ham, C., Hendriks, J., \& Sloof, D. (2020). COVID-19: Een analyse van de nationale crisisrespons. Crisis University Press.

Bouckaert, G., Galli, D., Kuhlmann, S., Reiter, R., \& Van Hecke, S. (2020). European colonialism? A hot spot governing a pandemic crisis. Public Administration Review, 80(5), 765-773.

Bromfield, N., \& McConnell, A. (2020). Two routes to precarious success: Australia, New Zealand, COVID-19 and the politics of crisis governance. International Review of Administrative Sciences. https://doi.org/10.1177/ 0020852320972465.

Brooks, E., \& Geyer, R. (2020). The development of EU health policy and the Covid-19 pandemic: Trends and implications. Journal of European Integration, 42(8), 1057-1076. 
Cairney, P., \& Wellstead, A. (2020). COVID-19: Effective policymaking depends on trust in experts, politicians, and the public. Policy Design and Practice, 0, 1-19. https://doi.org/10.1080/25741292.2020.1837466.

Calabresi, G., \& Bobbit, P. (1979). Tragic choices. Norton.

Capano, G. (2020). Policy design and state capacity in the COVID-19 emergency in Italy: If you are not prepared for the (un)expected, you can only be what you already are. Policy and Society, 39(3), 326-344.

Capano, G., \& Galanti, M. T. (2018). Policy dynamics and types of agency: From individual to collective patterns of action. European Policy Analysis, 4(1), 2347.

Capano, G., Howlett, M., Jarvis, D. S. L., Ramesh, M., \& Goyal, N. (2020). Mobilizing policy (in)capacity to fight COVID-19: Understanding variations in state responses. Policy and Society, 39(3), 285-308.

Carter, D. P., \& May, P. J. (2020). Making sense of the U.S. COVID-19 pandemic response: A policy regime perspective. Administrative Theory o Practice, 42(2), 265-277.

Cheng, C., Barceló, J., Hartnett, A., Kubinec, R., \& Messerschmidt, L. (2020). COVID-19 government response event dataset (CoronaNet v1.0). Nature Human Behaviour. https://doi.org/10.1038/s41562-020-0909-7.

Cheng, Y., Yu, J., Shen, Y., \& Huang, B. (2020b). Coproducing responses to COVID-19 with community-based organizations: Lessons from Zhejiang Province, China. Public Administration Review, 80(5), 866-873.

Choi, Y. J. (2020). The power of collaborative governance: The case of South Korea responding to COVID-19 pandemic. World Medical \& Health Policy, $12(4), 430-442$.

Christensen, T., \& Laegreid, P. (2020). Balancing governance capacity and legitimacy: How the Norwegian government handled the COVID-19 crisis as high performer. Public Administration Review, 80(5), 774-779.

Christensen, T., Laegreid, P., \& Rykkja, L. (2016). Organizing for crisis management: Building governance capacity and legitimacy. Public Administration Review, 76(6), 887-897.

Clarke, L. (1999). Mission improbable: Using fantasy documents to tame disaster. University of Chicago Press.

Desson, Z., Lambertz, L., Peters, J. W., Falkenbach, M., \& Kauer, L. (2020). Europe's Covid-19 outliers: German, Austrian and Swiss policy responses during the early stages of the 2020 pandemic. Health Policy and Technology, $9(4), 405-418$.

Dostal, J. M. (2020). Governing under pressure: German policy making during the coronavirus crisis. The Political Quarterly, 91(3), 542-552.

Dror, Y. (1986). Policymaking under adversity. Transaction.

Dror, Y. (2001). The capacity to govern. Routledge. 
Drury, J. (2018). The role of social identity processes in mass emergency behaviour: An integrative review. European Review of Social Psychology, 29(1), 38-81.

Garrett, L. (1994). The coming plague: Newly coming diseases in a world out of balance. Farrar, Strauss and Giroux.

Hassenteufel, P. (2020). Handling the COVID-19 crisis in France: Paradoxes of a centralized state-led health system. European Policy Analysis, 6(2), 170-179.

Herrera, H., Konradt, M., Ordonez, G., \& Trebesch, C. (2020, November 6). The political consequences of the Covid pandemic: Lessons from crosscountry polling data. Vox EU. https://voxeu.org/article/political-consequen ces-covid-pandemic.

Jacobs, B. (1993). Riots in Britain and the United States: The bureau-politics of crisis management and urban policy. Journal of Contingencies and Crisis Management, 1(3), 152-163.

Jamieson, T. (2020). "Go hard, go early": Preliminary lessons from New Zealand's response to COVID-19. American Review of Public Administration, 50(6-7), 598-605.

Jennings, W., Valgarosson, V., Stoker, G., Devine, D., Gaskell, J., \& Evans, M. (2020). Political trust and the Covid-19 crisis: Pushing populism to the back burner? Democracy 2025. https://www.democracy2025.gov.au/resour ces.html.

Johnson, I. (2020). How did China beat its Covid crisis? The New York Review of Books. https://www.nybooks.com/articles/2020/11/05/how-did-chinabeat-its-covid-crisis/.

Kalkman, J., Kerstholt, J., \& Roelofs, M. (2018). Crisis response team decisionmaking as a bureau-political process. Journal of Contingencies and Crisis Management, 26(4), 480-490.

Kim, D., \& Kreps, G. (2020). An analysis of government communication in the United States during the COVID-19 pandemic: Recommendations for effective government health risk communication. World Medical \& Health Policy, 12(4), 398-412.

Ladi, S., \& Tsarouhas, D. (2020). EU economic governance and Covid-19: Policy learning and windows of opportunity. Journal of European Integration, 42(8), 1041-1056.

Lasswell, H. (1936). Politics: Who gets what, when, and how. Whittlesey House.

Lodge, M., \& Wegrich, K. (Eds.). (2014). The problem-solving capacity of the modern state: Governance challenges and administrative capacities. Oxford University Press.

Maor, M., Sulitzeanu-Kenan, R., \& Chinitz, D. (2020). When COVID-19, constitutional crisis, and political deadlock meet: The Israeli case from a disproportionate policy perspective. Policy and Society, 39(3), 442-457. 
Migone, A. R. (2020). Trust, but customize: Federalism's impact on the Canadian COVID-19 response. Policy and Society, 39(3), 382-402.

Park, S., \& Maher, C. S. (2020). Government financial management and the coronavirus pandemic: A comparative look at South Korea and the United States. American Review of Public Administration, 50(6-7), 590-597.

Parker, C. F., Nohrstedt, D., Baird, J., Hermansson, H., Rubin, O., \& Baekkeskov, E. (2020). Collaborative crisis management: A plausibility probe of core assumptions. Policy and Society, 39(4), 510-529.

Polischuk, L., \& Fay, D. L. (2020). Administrative response to consequences of COVID-19 emergency responses: Observations and implications from genderbased violence in Argentina. American Review of Public Administration, $50(6-7), 675-684$.

Pressman, J., \& Wildavsky, A. (1973). Implementation. University of California Press.

Rachman, G. (2020, December 29). The perverse effects of COVID-19. Financial Times, p. 17.

Rauhaus, B. M., Sibila, D., \& Johnson, A. F. (2020). Addressing the increase of domestic violence and abuse during the COVID-19 pandemic: A need for empathy, care, and social equity in collaborative planning and responses. American Review of Public Administration, 50(6-7), 668-674.

Rosenberg, C. (1992). Explaining epidemics. Cambridge University Press.

Rosenthal, U., 't Hart, P., \& Kouzmin, A. (1991). The bureau-politics of crisis management. Public Administration, 69(2), 211-233.

Rozell, M. J., \& Wilcox, C. (2020). Federalism in a time of plague: How federal systems cope with pandemic. American Review of Public Administration, 50(6-7), 519-525.

Schmidt, V. (2020). Theorizing institutional change and governance in European Responses to the Covid-19 pandemic. Journal of European Integration, 42(8), 1177-1193.

Schmitt, C. (2006). Political theology. University of Chicago Press.

't Hart, P., \& Boin, A. (2001). Between crisis and normalcy: The long shadow of post-crisis politics. In U. Rosenthal, A. Boin, \& L. K. Comfort (Eds.), Managing crises: Threats, dilemmas, opportunities (pp. 28-48). Charles C. Thomas.

't Hart, P., Rosenthal, U., \& Kouzmin, A. (1993). Crisis decisionmaking: The centralization thesis revisited. Administration and Society, 25(1), 12-45.

Turrini, A., Cristofoli, D., \& Valotti, G. (2020). Sense or sensibility? Different approaches to cope with the COVID-19 pandemic. American Review of Public Administration. https://doi.org/10.1177/0275074020942427.

Van Delden, M. (2018). The influence of crisis management on leadership capital: A case study of the crisis of the crash of flight MH17. Public Note, 2(2), 13-22. 
Van Overbeke, T., \& Stadig, D. (2020). High politics in the low countries: COVID-19 and the politics of strained multi-level policy cooperation in Belgium and the Netherlands. European Policy Analysis, 6(2), 305-317.

Vecchi, V., Cusumano, N., \& Boyer, E. J. (2020). Medical supply acquisition in Italy and the United States in the era of COVID-19: The case for strategic procurement and public-private partnerships. American Review of Public Administration, 50(6-7), 642-649.

Wolff, S., \& Ladi, S. (2020). European Union responses to the Covid-19 pandemic: Adaptability in times of permanent emergency. Journal of European Integration, 42(8), 1025-1040.

Wright, L. (2021, January). The plague year: The mistakes and struggles behind America's coronavirus tragedy. New Yorker. https://www.newyorker.com/ magazine/2021/01/04/the-plague-year.

Young, S. L., Wiley, K. K., \& Searing, E. A. M. (2020). "Squandered in real time": How public management theory underestimated the public administration-politics dichotomy. American Review of Public Administration, $50(6-7), 480-488$.

Zaki, J. (2020). Catastrophe compassion: Understanding and extending prosociality under crisis. Trends in Cognitive Sciences, 24(8), 587-589.

Open Access This chapter is licensed under the terms of the Creative Commons Attribution 4.0 International License (http://creativecommons.org/licenses/ by $/ 4.0 /)$, which permits use, sharing, adaptation, distribution and reproduction in any medium or format, as long as you give appropriate credit to the original author(s) and the source, provide a link to the Creative Commons license and indicate if changes were made.

The images or other third party material in this chapter are included in the chapter's Creative Commons license, unless indicated otherwise in a credit line to the material. If material is not included in the chapter's Creative Commons license and your intended use is not permitted by statutory regulation or exceeds the permitted use, you will need to obtain permission directly from the copyright holder.

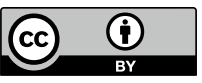

